\title{
Integrasi Konseling Kelompok Cognitive Behavior Therapy dengan Passive Music Therapy untuk Mereduksi Academic Anxiety, Efektifkah?
}

\author{
Dominikus David Biondi Situmorang ${ }^{1}$, M. Mulawarman², Mungin Eddy Wibowo ${ }^{2}$ \\ ${ }^{1}$ Program Studi Bimbingan dan Konseling, Fakultas Pendidikan dan Bahasa, Universitas Katolik Indonesia \\ Atma Jaya Jakarta \\ Jl. Jenderal Sudirman No. 51, Jakarta Selatan, Daerah Khusus Ibukota Jakarta, Indonesia 12930 \\ ${ }^{2}$ Jurusan Bimbingan dan Konseling, Fakultas Ilmu Pendidikan, Universitas Negeri Semarang \\ Jl. Sekaran, Semarang, Jawa Tengah, Indonesia 50229 \\ E-mail: david.biondi@atmajaya.ac.id
}

Artikel diterima: 23 Maret 2018; direvisi 6 Mei 2018; disetujui 17 Mei 2018

\begin{abstract}
The aim of this study is to determine the effectiveness of group counseling with cognitive behavior therapy approach using passive music therapy technique to reduce the academic anxiety of students who is writing thesis. The research used quasi-experimental design (pretest, posttest, and follow-up). Group counseling was conducted for five meetings, and follow-up was performed two weeks after the treatment. Research subjects were seven students. Purposive sampling technique was used to select the subjects, that is based on inclusion criteria and level of academic anxiety which is obtained from academic anxiety scale $(\mathrm{rxy}=0.536-0.823$, coefficient alpha $=0.963)$. The results showed that group counseling with cognitive behavior therapy approach using passive music therapy technique was significantly effective to reduce the students' academic anxiety in pretest vs. posttest and pretest vs followup, but in posttest vs. follow-up there was a slight increase in academic anxiety. Passive music therapy which is integrated into group counseling with cognitive behavior counseling approach, it is not only able to solve the individual problems but also able to help individuals to analyze their thoughts and behaviors through passive music activities with guided imagery.
\end{abstract}

Keywords: group counseling; cognitive behavior therapy; passive music therapy; academic anxiety

\begin{abstract}
Abstrak: Tujuan penelitian ini untuk mengetahui efektivitas pelaksanaan konseling kelompok pendekatan cognitive behavior therapy (CBT) dengan teknik passive music therapy dalam mereduksi academic anxiety mahasiswa penyusun skripsi. Penelitian ini menggunakan desain quasi-eksperimental (pretest, posttest, dan follow-up). Konseling kelompok dilaksanakan selama lima pertemuan, dan follow-up dilakukan dua minggu setelah treatment. Subjek penelitian yang digunakan dalam penelitian ini yaitu tujuh mahasiswa. Pemilihan subjek menggunakan teknik purposive sampling yaitu didasarkan pada kriteria inklusi dan tingkat academic anxiety yang diperoleh dari academic anxiety scale ( $\mathrm{rxy}=0.536-0.823$, coefficient $a l p h a=0.963$ ). Hasil penelitian menunjukkan bahwa konseling kelompok pendekatan $C B T$ dengan teknik passive music therapy secara signifikan efektif untuk mereduksi academic anxiety mahasiswa pada saat pretest vs posttest dan pretest vs follow-up, namun pada saat posttest vs follow-up terjadi sedikit peningkatan academic anxiety. Passive music therapy yang diintegrasikan dalam konseling kelompok pendekatan $C B T$ tidak hanya dapat mengatasi masalah individu, tetapi juga dapat membantu individu menganalisis pikiran dan perilaku mereka sendiri, melalui aktivitas musik pasif dengan guided imagery.
\end{abstract}

Kata kunci: konseling kelompok; CBT; passive music therapy; academic anxiety 
Dewasa ini, skripsi merupakan tugas akhir yang mengakibatkan kecemasan yang tinggi bagi sebagian besar mahasiswa di Indonesia (Situmorang, in press, 2017a, 2017b, 2018). Jika ditelisik lebih mendalam, banyak di antara mahasiswa yang masih belum memiliki kecakapan menulis yang mumpuni, serta tidak memiliki ketertarikan terhadap penelitian. Lebih lanjut, rendahnya motivasi berprestasi dan kreativitas mahasiswa dalam upaya penyelesaian tugas akhir ini, merupakan beberapa prediktor yang dapat menjadi sorotan (Situmorang, 2016). Oleh sebab itu, akhirnya banyak di antara mahasiswa yang melakukan prokrastinasi, menghindari dosen pembimbing, melakukan hal-hal yang non-produktif, dan yang paling ekstrem ialah melakukan bunuh diri (Situmorang, in press, 2017a, 2017b, 2018).

Hal-hal yang telah disebutkan tersebut merupakan gejala academic anxiety (Ottens, 1991). Academic anxiety terhadap skripsi ialah suatu perasaan cemas berlebihan terhadap tugas akhir ilmiah yang sangat mengganggu perhatian, konsentrasi, dan kesejahteraan hidup. Mahasiswa yang mengalami academic anxiety akan merasakan kondisi kognitif, afektif, psikis, dan perilaku yang maladaptif (Situmorang, 2017b, 2018). Berkaitan dengan hal tersebut, dirasa cukup penting untuk melakukan sebuah layanan preventif untuk mencegah fenomena ini di bagian hulu, dan melakukan layanan kuratif bagi mereka yang mengalami academic anxiety di bagian hilir (Situmorang, 2017a, 2018). Para konselor pendidikan di perguruan tinggi diharapkan untuk selalu bersikap proaktif dalam mencegah maupun mengobati para mahasiswa yang mengalami academic anxiety terhadap skripsi. Selain itu, para konselor pendidikan diharapkan dapat melakukan sebuah layanan intervensi konseling yang lebih efektif dan optimal dalam menanggulangi permasalahan ini. Salah satu layanan intervensi konseling modern yang ditawarkan oleh integrative approach adalah melalui musik (Bastemur, Dursun-Bilgin, Yildiz, \& Ucar, 2016; Capuzzi \& Stauffer, 2016; Sharf, 2015).

Penggunaan musik dalam konseling dapat meningkatkan produksi keempat hormon positif yang ada di dalam tubuh manusia, yaitu endorphin; dopamine; serotonin; dan oxytocin (Mucci \& Mucci, 2000; Vianna, Barbosa, Carvalhaes, \& Cunha, 2011). Fungsi dari keempat hormon positif tersebut dapat membuat tubuh menjadi lebih rileks; mereduksi kecemasan atau stres; meningkatkan kebahagiaan; meningkatkan kecerdasan; dan meningkatkan rasa percaya diri (Djohan, 2006; Mucci \& Mucci, 2000).

Pemberian music therapy sebagai salah satu teknik dalam layanan intervensi untuk membantu mahasiswa dalam mereduksi academic anxiety akan jauh lebih efektif dibandingkan dengan layanan intervensi konseling konvensional yang selama ini dilakukan oleh konselor pendidikan. Hal ini dikarenakan dengan music therapy, mahasiswa dapat mereduksi kecemasannya terhadap skripsi dan meningkatkan rasa percaya diri dalam menyelesaikan skripsi (Situmorang, in press, 2017a, 2017b, 2018).

Musik, yang disukai banyak orang (Salimpoor \& Zatorre, 2013), telah diperkenalkan penggunaannya dalam konseling di tahun 1992 (Gladding, 2016). Musik digunakan sebagai media untuk menenangkan, dan membantu konseli untuk merasa nyaman, sehingga proses konseling menjadi lebih efektif. Musik juga dapat digunakan untuk mengelola emosi seseorang (Irani, Handarini, \& Fauzan, 2018). Penggunaan musik dalam proses konseling dikenal sebagai music therapy. Beberapa ahli mengkaji bahwa music therapy sebagai salah satu bentuk intervensi terapi ekspresif/seni kreatif dalam pendekatan konseling integratif (integrative approach), yang dapat diterapkan dalam proses konseling (Bastemur et al., 2016; Capuzzi \& Stauffer, 2016; Sharf, 2015). Dalam proses konseling modern, para konselor diharapkan dapat mengintegrasikan terapi seni dalam proses bantuan terhadap konseli (Gladding, 2016). Salah satu terapi seni yang dapat menembus batas-batas budaya ialah melalui musik. Siapapun menyukai musik, tanpa memandang usia, gender, suku, agama, ras, latar belakang pendidikan, dan lainnya (Djohan, 2006).

Dalam penerapannya, music therapy dibagi menjadi dua, yaitu passive music therapy dan active music therapy (Wigram, Pedersen, \& Bonde, 2002). Passive music therapy adalah pemberian terapi musik yang dilakukan dengan cara mengajak konseli untuk mendengarkan sebuah instrumen tertentu secara seksama. Sementara, active music therapy adalah proses pemberian terapi musik yang 
dilakukan dengan cara mengajak konseli untuk memainkan sebuah instrumen, bernyanyi, maupun menciptakan lagu. Kedua teknik music therapy ini dapat dilakukan melalui konseling individual maupun kelompok.

Dalam ranah bimbingan dan konseling (BK), konseling kelompok adalah proses interpersonal yang dipimpin oleh konselor yang terlatih secara profesional dan dilaksanakan dengan individuindividu yang sedang menghadapi problema perkembangan khusus. Hal itu berfokus pada pikiran, perasaan, sikap, nilai, tujuan tingkah laku dan tujuan individu serta grup secara keseluruhan (Corey, 2016; Gibson \& Mitchell, 2003; Wibowo, 2005).

Perkembangan music therapy di dunia dewasa ini dalam praktiknya banyak berpusat pada teori behavior, yang secara spesifik lebih mengarah pada CBT (Wigram, Pedersen, \& Bonde, 2002). Penelitian mutakhir mengenai music therapy yang berpusat pada teori $C B T$ dalam pelaksanaan konseling pun telah banyak dilakukan (Baker, Gleadhill, \& Dingle, 2007; Fredenburg \& Silverman, 2014; Rogers, Ei, Rogers, \& Cross, 2007; Vargas, 2015; Zhang et al., 2017)

Berdasarkan konsep adaptasi Music Therapy based on Cognitive Behavior Therapy (Wigram, Pedersen, \& Bonde, 2002), seorang mahasiswa yang mengalami academic anxiety disebabkan distorsi kognitif atau pikiran-pikiran negatif terkait ketidakberdayaan atau ketidakmampuannya dalam hal akademik. Distorsi kognitif terbentuk dari core belief yang telah menetap, yaitu merupakan keyakinan paling dasar tentang diri, adanya keyakinan tidak mampu secara akademik, dan keyakinan tidak berdaya. Keyakinan-keyakinan ini terbentuk berdasarkan pengalaman atau peristiwa yang dialami oleh individu. Dengan demikian, ketika individu mengalami masalah terkait academic anxiety, maka hal yang perlu dilakukan adalah dengan membantu individu merestrukturisasi pikiran-pikiran negatif yang dimiliki menuju pikiran-pikiran yang lebih adaptif (Situmorang, 2017b, 2018).

Penggunakan teknik passive music therapy yang berpusat pada $C B T$, diharapkan dapat membantu anggota kelompok yang menunjukkan academic anxiety terhadap skripsi, agar mereka mampu menyadari kecemasan yang dirasakan. Setelah mereka menyadari kecemasan tersebut, mereka mengevaluasi kecemasannya berdasarkan pengalaman masa lalu yang tidak menyenangkan. Selanjutnya mereka berdamai dengan pengalaman masa lalunya tersebut, dan mengoptimalkan kemampuan yang dimiliki, agar dapat menyelesaikan skripsi dengan baik melalui aktivitas mendengarkan musik secara reseptif/pasif dengan guided imagery (Situmorang, in press, 2018).

Kenyataan di Indonesia, penerapan dan penelitian music therapy dalam praktik konseling masih jarang ditemukan. Penelitian mengenai pengaruh musik sebagai media terapi terhadap stres akademik mahasiswa pernah dilakukan (Rosanty, 2014). Dari hasil penelitian tersebut, musik dapat digunakan sebagai intervensi untuk menurunkan stres akademik yang dialami oleh mahasiswa. Namun, penelitian ini hanya membuktikan penggunaan musik Mozart sebagai media penurunan stres akademik, dan belum mengkaji tentang pemberian musik sebagai suatu teknik dari integrative approach yang dapat dintegrasikan ke dalam praktik konseling dengan pendekatan konvensional yang sudah ada sampai saat ini (Degges-White \& Davis, 2017).

Berdasarkan hal tersebut, perlu dilakukan penelitian lebih lanjut mengenai pemberian terapi musik dengan teknik passive music therapy yang diintegrasikan dengan salah satu pendekatan konseling konvensional yaitu $C B T$, guna membuktikan keefektifannya dalam mereduksi academic anxiety mahasiswa penyusun skripsi. Hipotesis yang diajukan dalam penelitian ini adalah konseling kelompok CBT dengan teknik passive music therapy efektif dalam mereduksi academic anxiety mahasiswa penyusun skripsi.

\section{METODE}

Penelitian ini menggunakan konseling kelompok $C B T$ dengan teknik passive music therapy sebagai variabel bebas atau treatment, dan academic anxiety sebagai variabel terikat. Konseling kelompok $C B T$ dengan teknik passive music therapy adalah layanan yang diberikan untuk membantu anggota kelompok yang menunjukkan academic anxiety terhadap skripsi dengan merestrukturisasi pikiran-pikiran negatif yang dimiliki agar lebih adaptif, melalui aktivitas mendengarkan musik 
secara reseptif/pasif dengan guided imagery. Sementara, academic anxiety adalah suatu dorongan pikiran dan perasaan yang tidak menyenangkan dalam diri mahasiswa, sebagai akibat dari perasaan cemas yang berlebihan berkaitan dengan proses penyusunan skripsi. Pengukuran academic anxiety tersebut berdasarkan lima indikator, yaitu: pola kecemasan yang menimbulkan aktivitas mental (patterns of anxiety-engendering mental activity); perhatian yang menunjukkan arah yang salah (misdirected attention); distres secara fisik (physiological distress); dan perilaku yang kurang tepat (inappropriate behaviors).

Subjek penelitian dalam penelitian ini adalah tujuh orang mahasiswa BK Universitas Katolik Indonesia Atma Jaya penyusun skripsi yang memiliki academic anxiety tinggi. Pemilihan subjek ini menggunakan teknik purposive sampling (non-random). Pemilihan subjek penelitian didasarkan pada kriteria inklusi dan berdasarkan tingkat academic anxiety seperti disajikan pada tabel 1 . Subjek penelitian yang telah dipilih berdasarkan academic anxiety scale, hasilnya dijadikan sebagai pretest. Pretest dilakukan untuk mengetahui gambaran awal kondisi academic anxiety mahasiswa sebelum diberikan treatment dan kemudian untuk dibandingkan dengan posttest dan follow-up.

Instrumen utama yang digunakan dalam penelitian adalah academic anxiety scale yang peneliti kembangkan berdasarkan pada teori academic anxiety (Ottens, 1991). Academic anxiety scale terdiri dari 24 butir. Pada alat ukur tersebut, proses validasi ahli (expert judgement) dan uji coba instrumen dilakukan sebanyak dua kali. Hasil uji instrumen dinyatakan valid $\left(\mathrm{r}_{\mathrm{xy}}=0.536-0.823\right)$ dengan coefficient alpha sebesar 0.963 .

Metode penelitian yang digunakan ialah quasi-eksperimental. Penelitian ini menggunakan tiga kali pengukuran (pretest, posttest, follow-up). Pretest berupa pemberian instrumen pengumpulan data (academic anxiety scale) sebelum diberikan treatment. Treatment yang diberikan adalah konseling kelompok $C B T$ dengan teknik passive music therapy sebanyak lima pertemuan, dengan frekuensi pertemuan satu kali dalam seminggu, dan durasi 100 menit setiap pertemuan. Posttest berupa pemberian instrumen pengumpulan data yang diberikan setelah treatment. Kemudian, follow-up berupa pemberian kembali instrumen pengumpulan data setelah diberikan treatment dan dilaksanakan dua minggu setelah diberikan posttest. Secara khusus pada saat follow-up, setiap anggota kelompok diberikan wawancara singkat terkait hal-hal yang telah dilakukan selama dua minggu pemberian treatment. Tujuannya ialah untuk mengetahui perubahan academic anxiety yang dialami oleh para subjek berdasarkan gejala yang dialami, aktivitas musik yang dilakukan, dan progres dari pengerjaan skripsi (proses pelaksanaan konseling CBT dengan teknik passive music therapy - guided imagery dijelaskan secara detail dalam appendix 1 dan 2).

Teknik analisis yang digunakan dalam penelitian ini ialah one-way analysis of variance (ANOVA) repeated measures dengan menggunakan bantuan program Microsoft Excel 2016 dan IBM SPSS for Windows versi 23. Tujuan dari penggunaan teknik analisis ini ialah untuk menguji hipotesis guna mengetahui efektivitas konseling kelompok CBT dengan teknik passive music therapy berdasarkan data pretest, posttest, dan follow-up.

\section{Tabel 1 Kriteria Inklusi dan Ekslusi}

\begin{tabular}{|c|c|c|}
\hline No & Kriteria Inklusi & Kriteria Eksklusi \\
\hline 1 & $\begin{array}{l}\text { Mahasiswa yang sedang mengerjakan skripsi } \\
\text { pada bab I, bab II, dan bab III. }\end{array}$ & $\begin{array}{l}\text { Mahasiswa yang belum merampungkan skripsi } \\
\text { pada bab I, bab II, dan bab III. }\end{array}$ \\
\hline 2 & $\begin{array}{l}\text { Mahasiswa yang memiliki academic anxiety } \\
\text { yang sedang hingga tinggi dengan rentang } \\
\text { skor } 56-87 \text { dan } 88-120 \text { berdasarkan klasifikasi } \\
\text { academic anxiety scale. }\end{array}$ & $\begin{array}{l}\text { Mahasiswa yang memiliki academic anxiety } \\
\text { yang rendah dengan rentang skor } 24-55 \\
\text { berdasarkan academic anxiety scale. }\end{array}$ \\
\hline 3 & $\begin{array}{l}\text { Mahasiswa tersebut mau berpartisipasi secara } \\
\text { sukarela dalam penelitian ini. }\end{array}$ & $\begin{array}{l}\text { Mahasiswa yang tidak dapat diajak untuk } \\
\text { bekerjasama dan tidak bersedia untuk menjadi } \\
\text { responden. }\end{array}$ \\
\hline
\end{tabular}




\section{HASIL}

Data yang terkumpul (pretest, posttest, follow-up) ditabulasikan sebelum dilakukan analisis seperti yang tersaji pada tabel 2 dan gambar 1 . Kondisi academic anxiety sebelum mendapatkan treatment (pretest) berada pada kondisi yang tinggi. Setelah mendapatkan treatment (posttest), tingkat academic anxiety mahasiswa menurun menjadi rendah, namun setelah dua minggu pemberian treatment (follow-up), academic anxiety mengalami sedikit peningkatan.

Berdasarkan hasil pretest rata-rata tingkat academic anxiety mahasiswa termasuk dalam kriteria tinggi $(\mathrm{M}=94.71, \mathrm{SD}=5.407)$. Setelah diberikan treatment berupa konseling kelompok pendekatan $C B T$ dengan teknik passive music therapy, academic anxiety mahasiswa mengalami penurunan yang sangat drastis pada saat posttest $(\mathrm{M}=47.71, \mathrm{SD}=4.386)$. Namun, setelah dua minggu pemberian treatment, academic anxiety sedikit meningkat pada saat follow-up $(\mathrm{M}=53.86$, $\mathrm{SD}=8.295$ ). Selanjutnya, dari hasil analisis yang tersaji pada tabel 3 terlihat bahwa konseling kelompok pendekatan $C B T$ dengan teknik passive music therapy efektif dalam mereduksi academic anxiety mahasiswa $(\mathrm{F}=117.505, p<0.01)$.

Hasil analisis perbandingan (pairwise) juga menunjukkan besaran nilai perolehan pada pengukuran academic anxiety yang disajikan pada tabel 4 dan gambar 2. Besaran nilai penurunan academic anxiety dari efektivitas konseling kelompok pendekatan $C B T$ dengan teknik passive music therapy pada pretest $v$ s posttest $(\mathrm{MD}=47.000, \mathrm{SE}=2.795, p<0.01)$. Kemudian, pada pretest $v s$ follow-up $(\mathrm{MD}=40.857, \mathrm{SE}=4.056, p<0.01)$. Pada posttest vs follow-up $(\mathrm{MD}=-6.143, \mathrm{SE}=$ $3.011, p>0.01)$.

Berdasarkan hasil perolehan pengujian data, dapat diketahui bahwa konseling kelompok pendekatan $C B T$ dengan teknik passive music therapy secara signifikan dapat mereduksi academic anxiety mahasiswa BK Universitas Katolik Indonesia Atma Jaya Jakarta pada saat pretest vs posttest dan pretest vs follow-up, namun pada saat posttest vs follow-up terjadi sedikit peningkatan.

Tabel 2 Data Deskriptif Skor Academic Anxiety

\begin{tabular}{ccccc}
\hline No & Subjek & Pretest & Posttest & Follow-up \\
\hline 1 & AMYP & 97 & 45 & 63 \\
2 & RC & 100 & 50 & 43 \\
3 & MM & 95 & 52 & 65 \\
4 & FAO & 92 & 53 & 58 \\
5 & ERC & 87 & 43 & 50 \\
6 & TK & 90 & 49 & 51 \\
7 & MDA & 102 & 42 & 47 \\
\hline
\end{tabular}

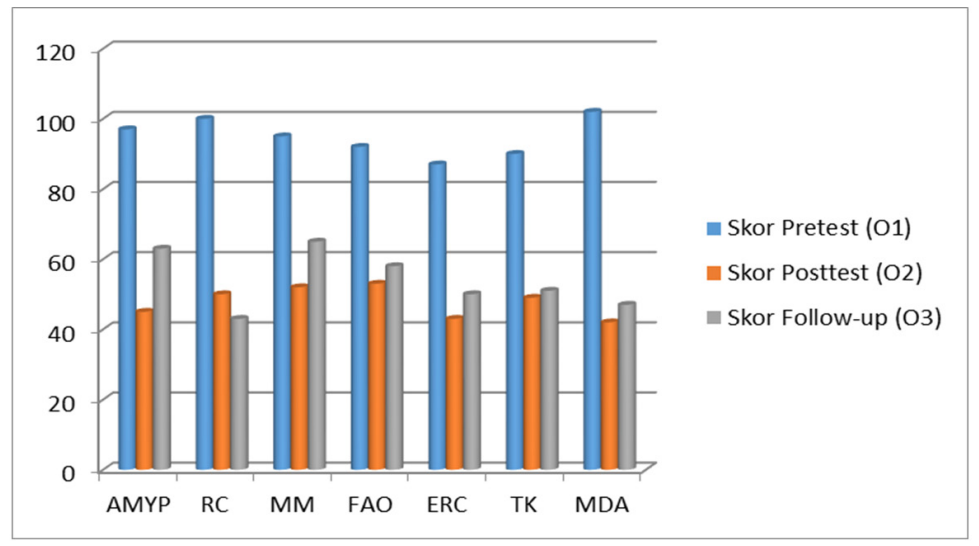

Gambar 1 Grafik Skor Academic Anxiety 
Tabel 3 Hasil One-Way ANOVA Repeated Measures

\begin{tabular}{cccc}
\hline Parameter & Pretest & Posttest & Follow-up \\
\hline Mean Std. & 94.71 & 47.71 & 53.86 \\
Deviation & 5.407 & 4.386 & 8.295 \\
F $(2,12)$ & & 117.505 & \\
$p$ & & $<0,01$ &
\end{tabular}

Tabel 4 Hasil Pairwise Comparisons

\begin{tabular}{clccc}
\hline No & Perbandingan & $\boldsymbol{M D}$ & $\boldsymbol{S E}$ & $\boldsymbol{p}$ \\
\hline 1 & Pretest vs. Posttest & 47.000 & 2.795 & $<0.01$ \\
2 & Pretest vs. Follow-up & 40.857 & 4.056 & $<0.01$ \\
3 & Posttest vs. Follow-up & -6.143 & 3.011 & $>0.01$ \\
\hline
\end{tabular}

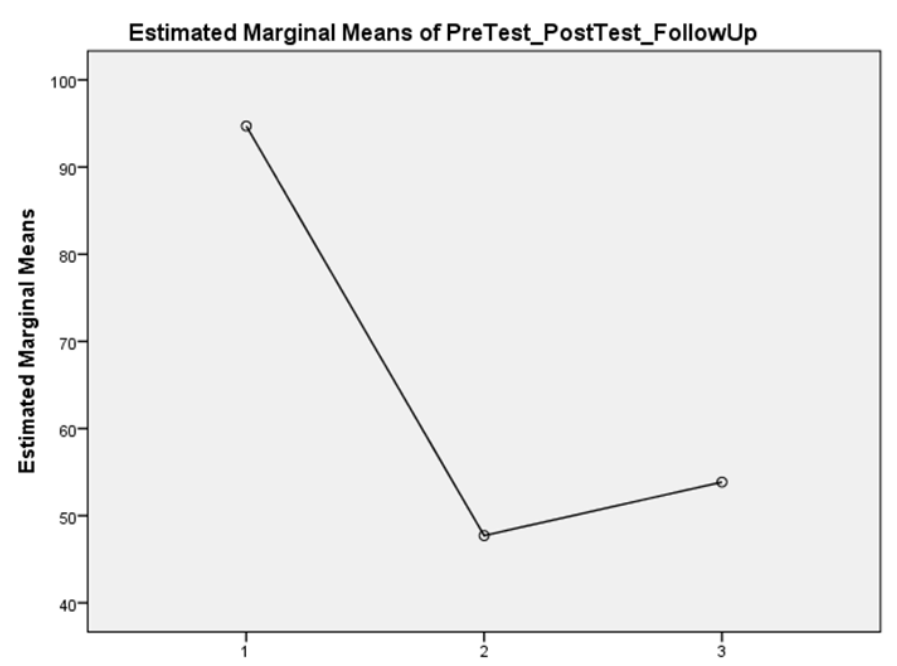

Gambar 2 Grafik Estimated Marginal Means

\section{PEMBAHASAN}

Secara umum, teknik passive music therapy yang diintegrasikan dalam konseling kelompok pendekatan $C B T$ efektif dalam mereduksi tingkat academic anxiety mahasiswa BK Universitas Katolik Indonesia Atma Jaya Jakarta. Hal ini sesuai dengan konsep the creative arts in counseling untuk membantu konseli dengan cara yang lebih menyenangkan (Gladding, 2016). Senada dengan hasil penelitian yang dilakukan sebelumnya (Degges-White \& Davis, 2017; Gladding, Newsome, Binkley, \& Henderson, 2008), music therapy sebagai bagian dari teori integrative/creative art approach yang dapat diintegrasikan dengan pendekatan konseling konvensional, terbukti efektif dalam situasi zaman sekarang. Selain itu, salah satu penelitian multi komponen konseling CBT dengan menggunakan guided visualizations, cranial electrotherapy stimulation, dan vibroacoustic sound dalam music therapy terbukti efektif dalam membantu konseli (Rogers et al., 2007). Berdasarkan hasil penelitian tersebut, dengan mengintegrasikan passive music therapy ke dalam proses konseling kelompok pendekatan $C B T$, mahasiswa belajar untuk terlibat dalam pikiran yang lebih realistis terhadap academic anxiety, terutama jika mereka secara konsisten memiliki distorsi kognitif yang dilandasi oleh core belief yang maladaptif, maka mahasiswa akan cenderung untuk selalu terjebak dalam pikiran yang maladaptif (Situmorang, 2017b).

Hasil penelitian yang didapatkan dalam penelitian ini, mampu menjadi bukti bahwa teknik passive music therapy dengan guided imagery memberikan insight dalam positive imagination kepada individu untuk dapat memiliki pikiran yang lebih adaptif dari sebelumnya (Beck, 
Hansen, \& Gold, 2015; Fox \& McKinney, 2015). Hal ini sejalan dengan hasil penelitian yang menunjukkan bahwa penggunaan musik dalam proses konseling dapat secara efektif membantu individu memahami perkembangan emosi dan kognitif mereka, serta membantu merestrukturisasi pikiran yang maladaptif menjadi lebih adaptif (Skudrzyk et al., 2009). Di sisi lain, berdasarkan hasil pengamatan selama proses konseling berlangsung, setiap subjek sangat bersikap kooperatif dan menunjukkan ketertarikan dalam setiap aktivitas yang dilaksanakan. Hal ini senada dengan penelitian yang menunjukkan bahwa melalui musik, konselor dapat membuat proses konseling menjadi lebih menarik dan efektif (Bradley, Whiting, Hendricks, Parr, \& Jones Jr, 2008). Selain itu, musik dapat membantu konselor dan konseli dalam melakukan reframing ide, memfokuskan perspektif, eksternalisasi emosi, dan memperdalam pemahaman dari sebuah pengalaman atau masalah. Penggunaan musik dalam proses konseling memang memiliki cukup banyak manfaat terapeutik (Situmorang, in press, 2017a, 2017b, 2018).

Mayoritas subjek mengatakan setelah mendengarkan musik secara pasif, mereka merasa lebih rileks, tenang, damai, nyaman, sehingga tidak merasa cemas, dan khawatir seperti keadaan sebelumnya. Selain itu, efek terpenting dari hasil penelitian ini ialah dapat membantu dan memotivasi para subjek untuk mengerjakan skripsi tanpa menunda-nunda. Hal ini senada dengan beberapa temuan lain, yang menjelaskan bahwa mendengarkan atau memainkan musik dapat digunakan untuk menyembuhkan stres atau kecemasan, karena musik memiliki kekuatan untuk menciptakan keadaan rileksasi pada individu, sehingga keadaan rileks ini menyebabkan terjadinya keseimbangan metabolisme tubuh dan hormonal (Bibb, Castle, \& Newton, 2015; Çiftçi \& Öztunç, 2015; Djohan, 2006; Fox \& McKinney, 2015; Gutiérrez \& Camarena, 2015; Lilley, Oberle, \& Thompson, 2014; Rosanty, 2014).

Semua anggota kelompok mengalami penurunan academic anxiety secara drastis pada saat pretest vs posttest. Namun pada saat pretest vs follow-up, hanya terlihat ada satu subjek saja yang mengalami perubahan yang sangat mencolok yaitu mengalami penurunan academic anxiety. Sementara subjek yang lainnya tidak mengalami penurunan, dan justru memperlihatkan peningkatan academic anxiety. Subjek yang tampak mencolok tersebut ialah RC yang mengalami penurunan tingkat academic anxiety cukup tinggi saat posttest vs follow up. Hal ini menandakan bahwa efek dari passive music therapy yang dirasakan oleh RC bertahan dalam jangka waktu yang lama. RC mengaku bahwa intensitasnya dalam mendengarkan musik selama dua minggu ialah sebanyak tiga kali. Salah satu faktor yang terkait ketika seseorang mendengarkan dan memainkan musik adalah familiaritas, jadi semakin sering seseorang mendengarkan dan memainkan musik, maka nilai hedonisnya akan semakin meningkat (Djohan, 2010). Sementara itu, keenam subjek yang lain tampak mengalami kenaikkan skor academic anxiety saat posttest vs follow-up. Hal ini menunjukkan bahwa passive music therapy yang dirasakan oleh keenam subjek lainnya tidak bertahan dalam jangka waktu yang pendek, dan jika dilihat dari intensitas dalam mendengarkan musik, keenam subjek mendengarkan musik dalam jumlah yang cukup sedikit selama dua minggu.

\section{SIMPULAN}

Dalam penelitian ini dapat disimpulkan bahwa konseling kelompok pendekatan $C B T$ dengan teknik passive music therapy secara efektif mereduksi academic anxiety mahasiswa BK Universitas Katolik Indonesia Atma Jaya Jakarta, khususnya pada saat pretest vs posttest dan pretest vs followup. Meskipun pada saat posttest vs follow-up terjadi sedikit peningkatan academic anxiety, namun secara keseluruhan tingkat academic anxiety para mahasiswa tetap mengalami penurunan yang cukup signifikan. Berdasarkan hal tersebut, temuan penelitian ini dapat memberikan pemahaman baru bagi perkembangan keilmuan psikologi dan konseling di Indonesia, bahwa penggunaan pendekatan konseling konvensional $C B T$ yang diintegrasikan dengan music therapy terbukti efektif dalam mereduksi academic anxiety mahasiswa penyusun skripsi. 
Dari hasil penelitian ini, diharapkan para psikolog dan konselor di Indonesia dapat menggunakan konseling kelompok $C B T$ dengan teknik passive music therapy untuk membantu mahasiswa yang mengalami academic anxiety pada saat menyusun skripsi. Kemudian, diharapkan peneliti selanjutnya dapat menguji efektivitas active music therapy dalam hal yang sama, sehingga dapat memperkaya khazanah keilmuan psikologi dan konseling yang sesuai dengan perkembangan zaman saat ini.

\section{UCAPAN TERIMA KASIH}

Ucapan terima kasih disampaikan kepada P.V. Sriyani Wikarta, M.Pd., Kons. dari Program Studi Bimbingan dan Konseling, Universitas Katolik Indonesia Atma Jaya Jakarta, yang telah menjadi eksperimentor kedua dalam pemberian passive music therapy dengan guided imagery. Selain itu, ucapan terima kasih juga disampaikan kepada Saphira Hertha, S.Sn. sebagai Direktur Eksekutif dari Music Therapy Centre Indonesia yang telah memberikan short course mengenai music therapy kepada peneliti utama (eksperimentor pertama).

\section{DAFTAR RUJUKAN}

Baker, F. A., Gleadhill, L. M., \& Dingle, G. A. (2007). Music Therapy and Emotional Exploration: Exposing Substance Abuse Clients to The Experiences of Non-drug-induced Emotions. The Arts in Psychotherapy, 34(4), 321-330. https://doi.org/10.1016/j.aip.2007.04.005

Bastemur, S., Dursun-Bilgin, M., Yildiz, Y., \& Ucar, S. (2016). Alternative Therapies: New Approaches in Counseling. Procedia - Social and Behavioral Sciences, 217, 1157-1166. https:// doi.org/10.1016/j.sbspro.2016.02.135

Beck, B. D., Hansen, Å. M., \& Gold, C. (2015). Coping with Work-related Stress through Guided Imagery and Music (GIM): Randomized Controlled Trial. Journal of Music Therapy, 52(3), 323-352.

Bibb, J., Castle, D., \& Newton, R. (2015). The Role of Music Therapy in Reducing Post Meal Related Anxiety for Patients with Anorexia Nervosa. Journal of Eating Disorders, 3(1), 50. https://doi.org/10.1186/s40337-015-0088-5

Bradley, L. J., Whiting, P., Hendricks, B., Parr, G., \& Jones Jr, E. G. (2008). The Use of Expressive Techniques in Counseling. Journal of Creativity in Mental Health, 3(1), 44-59.

Capuzzi, D., \& Stauffer, M. D. (2016). Counseling and Psychotherapy: Theories and Interventions. John Wiley \& Sons.

Çiftçi, H., \& Öztunç, G. (2015). The Effect of Music on Comfort, Anxiety and Pain in the Intensive Care Unit: A Case in Turkey. International Journal of Caring Sciences, 8(3), 594-602.

Corey, G. (2016). Theory and Practice of Group Counseling. ( $9^{\text {th }}$ ed.). Belmont, CA: Brooks/Cole.

Degges-White, S., \& Davis, N. L. (2017). Integrating the Expressive Arts into Counseling Practice: Theory-based Interventions. New York: Springer Publishing Company.

Djohan. (2006). Terapi Musik: Teori dan Aplikasi. Yogyakarta: Galangpress.

Djohan. (2010). Respon Emosi Musikal. Bandung: Lubuk Agung.

Fox, E. I., \& McKinney, C. H. (2015). The Bonny Method of Guided Imagery and Music for Music Therapy Interns: A Survey of Effects on Professional and Personal Growth. Music Therapy Perspectives, 34(1), 90-98.

Fredenburg, H. A., \& Silverman, M. J. (2014). Effects of Cognitive-behavioral Music Therapy on Fatigue in Patients in A Blood and Marrow Transplantation Unit: A Mixed-method Pilot Study. The Arts in Psychotherapy, 41(5), 433-444. https://doi.org/10.1016/j.aip.2014.09.002

Gibson, R. L., \& Mitchell, M. (2003). Introduction to Counseling and Guidance. Merrill/Prentice Hall.

Gladding, S. T. (2016). The Creative Arts in Counseling. John Wiley \& Sons. 
Gladding, S. T., Newsome, D., Binkley, E., \& Henderson, D. A. (2008). The Lyrics of Hurting and Healing: Finding Words that are Revealing. Journal of Creativity in Mental Health, 3(3), 212-219.

Gutiérrez, E. O. F., \& Camarena, V. A. T. (2015). Music Therapy in Generalized Anxiety Disorder. The Arts in Psychotherapy, 44, 19-24.

Irani, L. C., Handarini, D. M., \& Fauzan, L. (2018). Pengembangan Panduan Pelatihan Keterampilan Mengelola Emosi sebagai Upaya Preventif Perilaku Bullying Siswa Sekolah Menengah Pertama. Jurnal Kajian Bimbingan dan Konseling, 3(1), 22-32. https://doi.org/10.17977/ um001v3i12018p022

Lilley, J. L., Oberle, C. D., \& Thompson, J. G. (2014). Effects of Music and Grade Consequences on Test Anxiety and Performance. Psychomusicology: Music, Mind, and Brain, 24(2), 184-190. https://doi.org/10.1037/pmu0000038

Mucci, K., \& Mucci, R. (2000). The Healing Sound of Music. Findhorn Press.

Ottens, A. J. (1991). Coping with Academic Anxiety. New York: The Rosen Publishing Group.

Rogers, D. R. B., Ei, S., Rogers, K. R., \& Cross, C. L. (2007). Evaluation of a Multi-component Approach to Cognitive-behavioral Therapy (CBT) Using Guided Visualizations, Cranial Electrotherapy Stimulation, and Vibroacoustic Sound. Complementary Therapies in Clinical Practice, 13(2), 95-101. https://doi.org/10.1016/j.ctcp.2006.10.002

Rosanty, R. (2014). Pengaruh Musik Mozart dalam Mengurangi Stres pada Mahasiswa yang Sedang Skripsi. Journal of Educational, Health and Community Psychology, 3(2), 71-78.

Salimpoor, V. N., \& Zatorre, R. J. (2013). Neural Interactions that Give Rise to Musical Pleasure. Psychology of Aesthetics, Creativity, and the Arts, 7(1), 62-75. https://doi.org/10.1037/a0031819

Sharf, R. S. (2015). Theories of Psychotherapy \& Counseling: Concepts and Cases. Cengage Learning.

Situmorang, D. D. B. (in press). Music Therapy bagi Mahasiswa Generasi Millenials, Perlukah? Buletin Psikologi.

Situmorang, D. D. B. (2016). Hubungan Antara Potensi Kreativitas dan Motivasi Berprestasi Mahasiswa Program Studi Bimbingan dan Konseling Angkatan 2010 FKIP Unika Atma Jaya. JBKI (Jurnal Bimbingan Konseling Indonesia), 1(1), 6-9. https://doi.org/10.26737/jbki.v1i1.97

Situmorang, D. D. B. (2017a). Efektivitas Pemberian Layanan Intervensi Music Therapy untuk Mereduksi Academic Anxiety Mahasiswa terhadap Skripsi. JBKI (Jurnal Bimbingan Konseling Indonesia), 2(1), 4. https://doi.org/10.26737/jbki.v2i1.242

Situmorang, D. D. B. (2017b). Mahasiswa Mengalami Academic Anxiety terhadap Skripsi? Berikan Konseling Cognitive Behavior Therapy dengan Musik. Jurnal Bimbingan dan Konseling ArRahman, 3(2), 31-42.

Situmorang, D. D. B. (2018). Keefektifan Konseling Kelompok Cognitive Behavior Therapy (CBT) Dengan Teknik Passive dan Active Music Therapy terhadap Academic Anxiety dan Self-efficacy. (Unpublished master's thesis). Program Pascasarjana, Universitas Negeri Semarang, Indonesia.

Skudrzyk, B., Zera, D. A., McMahon, G., Schmidt, R., Boyne, J., \& Spannaus, R. L. (2009). Learning to relate: Interweaving Creative Approaches in Group Counseling with Adolescents. Journal of Creativity in Mental Health, 4(3), 249-261.

Vargas, M. E. R. (2015). Music as A Resource to Develop Cognition. Procedia-Social and Behavioral Sciences, 174, 2989-2994.

Vianna, M. N. S., Barbosa, A. P., Carvalhaes, A. S., \& Cunha, A. J. L. (2011). Music Therapy May Increase Breastfeeding Rates Among Mothers Of Premature Newborns: A Randomized Controlled Trial. Jornal de Pediatria, 87(3), 206-212. 
Wibowo, M. E. (2005). Konseling Kelompok Perkembangan. Semarang: UNNES Press.

Wigram, T., Pedersen, I. N., \& Bonde, L. O. (2002). A Comprehensive Guide to Music Therapy: Theory, Clinical Practice, Research and Training. Music Therapy Perspectives. London: Jessica Kingsley Publishers. https://doi.org/10.1093/mtp/21.1.51

Zhang, Y., Cai, J., An, L., Hui, F., Ren, T., Ma, H., \& Zhao, Q. (2017). Does Music Therapy Enhance Behavioral and Cognitive Function in Elderly Dementia Patients? A Systematic Review And Meta-analysis. Ageing Research Reviews, 35, 1-11. https://doi.org/10.1016/j.arr.2016.12.003 